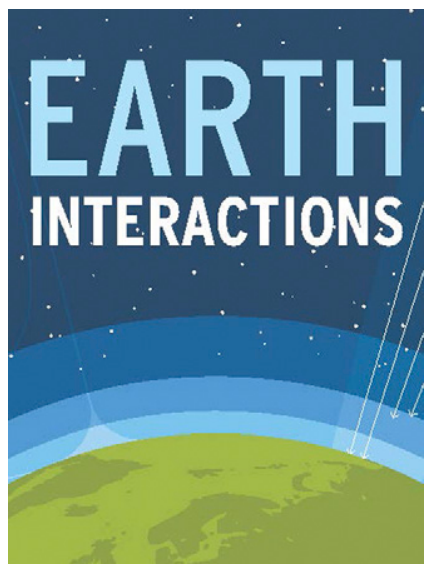

(C) 2017 American Meteorological Society. For information regarding reuse of this content and general copyright information, consult the AMS Copyright Policy (www.ametsoc.org/PUBSReuseLicenses).

\title{
Evidence that Recent Warming is Reducing Upper Colorado River Flows
}

\section{Gregory J. McCabe}

U.S. Geological Survey, Denver, Colorado

\section{David M. Wolock}

U.S. Geological Survey, Lawrence, Kansas

\section{Gregory T. Pederson}

U.S. Geological Survey, Bozeman, Montana

\section{Connie A. Woodhouse}

The University of Arizona, Tucson, Arizona

\section{Stephanie McAfee}

Nevada State Climate Office, University of Nevada, Reno, Nevada

Received 18 April 2017; in final form 4 October 2017

ABSTRACT: The upper Colorado River basin (UCRB) is one of the primary sources of water for the western United States, and increasing temperatures

\footnotetext{
${ }^{a}$ Corresponding author: Gregory J. McCabe, gmccabe@usgs.gov
} 
Earth Interactions - Volume 21 (2017) - Paper No. 10 • Page 2

likely will elevate the risk of reduced water supply in the basin. Although variability in water-year precipitation explains more of the variability in wateryear UCRB streamflow than water-year UCRB temperature, since the late 1980 s, increases in temperature in the UCRB have caused a substantial reduction in UCRB runoff efficiency (the ratio of streamflow to precipitation). These reductions in flow because of increasing temperatures are the largest documented temperature-related reductions since record keeping began. Increases in UCRB temperature over the past three decades have resulted in a mean UCRB water-year streamflow departure of -1306 million $\mathrm{m}^{3}$ (or $-7 \%$ of mean water-year streamflow). Additionally, warm-season (April through September) temperature has had a larger effect on variability in water-year UCRB streamflow than the cool-season (October through March) temperature. The greater contribution of warm-season temperature, relative to cool-season temperature, to variability of UCRB flow suggests that evaporation or snowmelt, rather than changes from snow to rain during the cool season, has driven recent reductions in UCRB flow. It is expected that as warming continues, the negative effects of temperature on water-year UCRB streamflow will become more evident and problematic.

KEYWORDS: Hydrology; Hydrometeorology; Water budget; Climate variability

\section{Introduction}

The Colorado River basin (Figure 1) extends across parts of seven states (Arizona, California, Colorado, New Mexico, Nevada, Utah, and Wyoming) and is one of the most important water resources in the western United States and Mexico (U.S. Bureau of Reclamation 2012). The upper Colorado River basin (UCRB) - that portion of the Colorado River basin upstream of the stream gauge at Lees Ferry-accounts for about $90 \%$ of the streamflow of the entire Colorado River basin (Jacobs 2011). Since the UCRB is the primary source of water in the Colorado River basin, this portion of the basin is the focus of our study.

There has been increased concern regarding future UCRB water supply given the effects of increasing temperatures on Colorado River streamflow and increases in consumptive water use in the basin (Diaz and Anderson 1995; U.S. Bureau of Reclamation 2012; Udall and Overpeck 2017). A number of studies have examined the effects of projected future warming on streamflow in the Colorado River basin (Christensen et al. 2004; Christensen and Lettenmaier 2007; Hoerling and Eischeid 2007; McCabe and Wolock 2007; Vano et al. 2014; Ficklin et al. 2013; Kopytkovskiy et al. 2015; Foster et al. 2016; Udall and Overpeck 2017). All of these studies have indicated that the adverse effects of future warming on Colorado River streamflows are likely to be considerable.

Recently, Woodhouse et al. (2016) examined the influence of precipitation, temperature, and antecedent soil moisture on UCRB water year (October through September) streamflow over the past 100 years. Results indicated that cool-season precipitation explains most of the variability in water-year streamflow; however, spring/summer temperature and, to a lesser extent, antecedent fall soil moisture appear to have substantial effects on UCRB streamflow under certain conditions. For example, the effects of recent droughts on UCRB streamflow have been amplified by increased temperatures, which exacerbated the effects of relatively modest precipitation deficits (Woodhouse et al. 2016). 


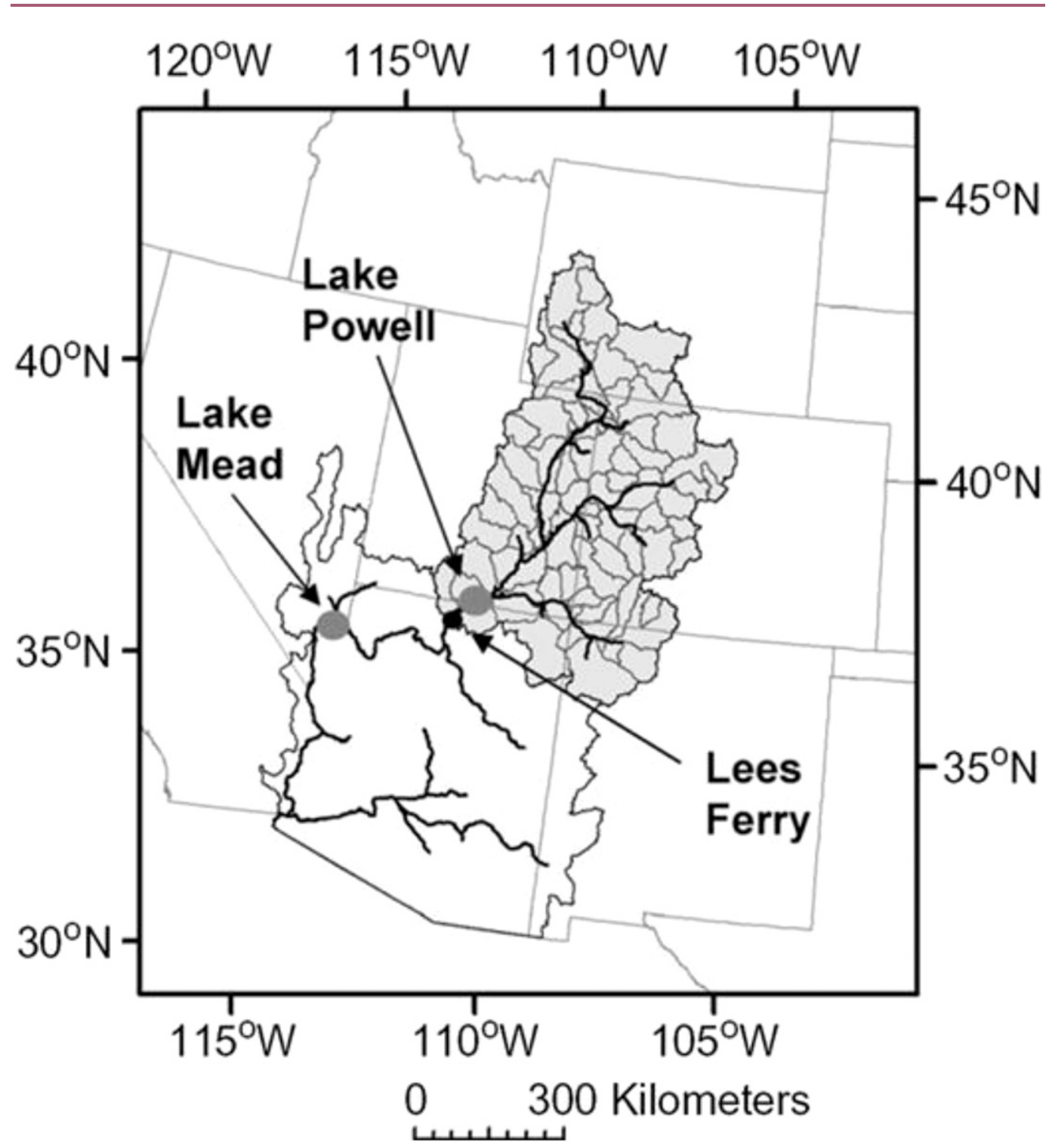

Figure 1. Map of the Colorado River basin. The upper Colorado River basin is shaded gray, and the boundaries for 62 hydrologic units are outlined in dark gray. Lakes Mead and Powell are the major reservoirs in the Colorado River system.

In another recent study, Udall and Overpeck (2017) examined the effect of temperatures on UCRB streamflow during the instrumental period and based on future projections from climate models. Udall and Overpeck point out that between 2000 and 2014, annual Colorado River streamflow averaged 19\% below the 190699 mean, the worst 15-yr drought on record. They attribute at least one-third of the decrease in UCRB streamflow during this period to increased temperature. Woodhouse et al. (2016) and Udall and Overpeck (2017) are the first studies to show a negative effect of recent warming on UCRB streamflow in the instrumental record. 
Earth Interactions - Volume 21 (2017) • Paper No. 10 • Page 4

Although climate model projections suggest a decrease in UCRB streamflow in part because of increases in temperature (Christensen et al. 2004; Christensen and Lettenmaier 2007; Hoerling and Eischeid 2007; McCabe and Wolock 2007; Vano et al. 2014; Ficklin et al. 2013; Kopytkovskiy et al. 2015; Udall and Overpeck 2017), there has been only sparse research that has qualitatively or quantitatively documented a negative effect of increases in temperature on UCRB streamflow in the instrumental record. Woodhouse et al. (2016) and Udall and Overpeck (2017) are the only studies to date that have addressed this issue, and they suggest that the effects of projected warming are becoming detectable. Given these previous studies and continued warming in the UCRB (Udall and Overpeck 2017), two critical questions need to be answered, namely, 1) are the effects of temperature on UCRB flow now substantial enough to be discernable amid natural UCRB flow variability, and 2) can these effects be quantified at both annual and seasonal time scales? Identification of the effects of increases in temperature on UCRB streamflow in the instrumental record can provide a benchmark for the magnitude of physically plausible, temperature-driven flow declines and lend credibility to model projections of future decreases in UCRB streamflow because of warming. The objectives of our analyses are to expand on the work by Woodhouse et al. (2016) and Udall and Overpeck (2017) using observed hydroclimatic data (1906-2012) to 1) detect and quantify the relative contributions of temperature and precipitation to water-year UCRB flow and 2) determine if increases in temperature are already having a statistically significant negative effect on UCRB streamflow.

\section{Data and methods}

Water-year (October-September) naturalized UCRB streamflow for the period 1906-2012 were obtained from the U.S. Bureau of Reclamation (http://www.usbr. gov/lc/region/g4000/NaturalFlow/current.html). Estimated natural flows have had the effects of diversions and depletions removed. For this study, the Lees Ferry streamflow record is used as it captures the flows for the entire UCRB. For the remainder of this paper, the naturalized UCRB streamflow will be referred to as measured streamflow. The time series of water-year streamflow was converted to units of million cubic meters $(\mathrm{mcm})$.

Monthly temperature $\left({ }^{\circ} \mathrm{C}\right)$ and precipitation $(\mathrm{mm})$ data for the period 1895 2014 were obtained from the Parameter-Elevation Regressions on Independent Slopes Model (PRISM) dataset (http://www.prism.oregonstate.edu/) on a $4 \mathrm{~km}$ by $4 \mathrm{~km}$ grid. The monthly temperature and precipitation data for PRISM grid cells in the UCRB were averaged or summed to compute mean water-year temperature and total water-year precipitation for each PRISM grid cell. The precipitation data also were converted to million cubic meters to be in the same units as streamflow. The time series of water-year temperature and precipitation for the PRISM grid cells in the UCRB subsequently were averaged to compute mean water-year UCRB temperature and precipitation for water years 1906-2012 for comparison with water-year UCRB streamflow. Additionally, water-year UCRB runoff efficiency was computed as water-year streamflow divided by water-year precipitation.

For most of the analyses presented in this paper, the time series are converted to $Z$ scores (number of standard deviations from the time series mean) to simplify 
comparison among variables and are smoothed with a 10 -yr moving average to remove some of the high-frequency noise in the time series.

The long length of the PRISM dataset (1895-present) was a primary reason for choosing these data for the analyses presented in this paper. However, because recent research has indicated temperature measurement errors for some highelevation snow telemetry sites in the western United States (Oyler et al. 2015a), we verified the PRISM monthly temperature data in a comparison with the Topoclimatic Daily Air Temperature Dataset for the Conterminous United States (TopoWx) data (Oyler et al. 2015b). The TopoWx temperature data have been adjusted for temperature measurement biases and are available for the 1948-2012 period (Oyler et al. 2015a, 2015b). Comparison between PRISM and TopoWX data for 1948-2012 indicated little to no difference in the time series from the two datasets (correlation coefficient $=0.9998$, PRISM bias relative to TopoWX $=$ $0.11^{\circ} \mathrm{C}$, and Nash-Sutcliffe statistic $\left.=0.9995\right)$. These results indicate that the UCRB temperature data obtained from the PRISM data are as reliable as TopoWX for our analyses.

To evaluate the relative importance of temperature and precipitation on UCRB streamflow, multiple linear regression analyses were performed over the years from 1906 through 2012. Mean measured water-year UCRB streamflow was used as the dependent variable, and mean water-year UCRB temperature and precipitation were the independent variables. Before performing the regression analyses, we examined statistical relations between the time series of water-year UCRB temperature, precipitation, and streamflow to ensure that regression analyses were appropriate. Specifically, the linearity, covariance, and normality of the datasets were examined.

Scatterplots (not shown) comparing water-year UCRB temperature, precipitation, and streamflow indicated that all of the variables are linearly related. None of the scatterplots indicated a nonlinear relation between any of the variables. Pearson correlations between the time series indicated a correlation between water-year UCBR flow and water-year UCRB temperature of $-0.57(p<0.05)$, a correlation between water-year UCRB flow and water-year UCRB precipitation of 0.77 ( $p<$ $0.05)$, and a correlation between water-year UCRB temperature and water-year UCRB precipitation of $-0.34(p<0.05)$. Although the correlation between UCRB temperature and UCRB precipitation is statistically significant, the correlation indicates that less than $12 \%$ of the variance in water-year UCRB precipitation is explained by water-year UCRB temperature. Partial correlation between wateryear UCRB temperature and water-year UCRB flow, controlling for water-year UCRB precipitation, is $-0.51(p<0.05)$, and the partial correlation between water-year UCRB precipitation and water-year UCRB flow, controlling for wateryear UCRB temperature, is $0.75(p<0.05)$. The magnitudes of the partial correlation values indicate that both precipitation and temperature have significant independent effects on UCRB streamflow.

Using a Kolmogorov-Smirnov test, we also examined whether the distributions of values from the time series of water-year temperature, precipitation, and streamflow were statistically different $(p<0.05)$ from a normal distribution. Results indicated that none of the time series had a distribution that was statistically different from a normal distribution. Thus, all of the time series can be considered to be normally distributed. 
Earth Interactions - Volume 21 (2017) • Paper No. 10 • Page 6

The statistical analyses described above indicate that the times series used in this study (i.e., water-year UCRB temperature, precipitation, and streamflow) can be appropriately analyzed using multiple linear regression.

\section{Results and discussion}

An evaluation of the time series of water-year streamflow, precipitation, and temperature indicates the importance of temperature and precipitation to streamflow variability over time. Figure 2 a illustrates 10 -yr moving averages of $Z$ scores of water-year UCRB precipitation and streamflow. These time series show that from 1906 to about 1933 the streamflow $Z$ scores are generally greater than the precipitation $Z$ scores (Figure 2a), indicating that during the early part of the twentieth century normalized streamflow values were higher than normalized precipitation values. This indicates a period of higher-than-average UCRB runoff efficiency (Figure 2c). This period of relatively high runoff efficiency for the UCRB (1906-33) is associated with negative temperature $Z$ scores (cooler-thanaverage temperature; Figure $2 \mathrm{~b}$ ). These temperatures are also consistent with a lower-than-average evaporative demand resulting in more streamflow per unit of precipitation (i.e., higher runoff efficiency; Figure 2c).

In the middle part of the record (1934-87), there are only small differences between the streamflow and precipitation $Z$ scores (Figure 2a). The similarity in streamflow and precipitation $Z$ scores during this period coincides with relatively consistent near-zero temperature $Z$ scores (near-average temperature; Figure 2b) and near-average runoff efficiency (Figure 2c).

Over the most recent decades (1988-2012), the precipitation $Z$ scores are generally larger than the streamflow $Z$ scores (Figure 2a), suggesting a decrease in runoff efficiency (Figure $2 \mathrm{c}$ ). This period also is associated with positive temperature $Z$ scores (higher-than-average temperature) and likely higher evaporative demand (Figure $2 b$ ).

The results described above indicate a substantial negative relationship between changes in runoff efficiency and variability in water-year UCRB temperature. When temperatures were below (above) the long-term average, runoff efficiency was above (below) the long-term average (Figures $2 \mathrm{~b}$ and $2 \mathrm{c}$ ). The correlation between the 10-yr moving average time series of water-year UCRB temperature and runoff efficiency is -0.87 ( $p<0.00001$; Figure 3 ).

These findings indicate that warming has had an increasingly negative influence on UCRB flow over recent decades. Woodhouse et al. (2016) reported that since 1988 there has been a notable increase in the frequency of warm years, which have resulted in lower than expected UCRB streamflow given the magnitude of precipitation, with recent streamflow droughts being exacerbated by higher-thanaverage temperature. The negative effect of temperature on water-year UCRB streamflow since the late 1980s is also consistent with research on changes in snowmelt and streamflow timing in the western United States. For example, Stewart et al. (2004) and McCabe and Clark (2005) showed a shift in the timing of streamflow in the western conterminous United States (CONUS) to earlier in the year. McCabe and Clark (2005) also reported that a shift in streamflow timing occurred during the mid-1980s and that it was related to a shift to increased temperature across the western United States. In addition, McCabe and Wolock (2009) reported decreases in snow water equivalent (SWE) for much of the western 


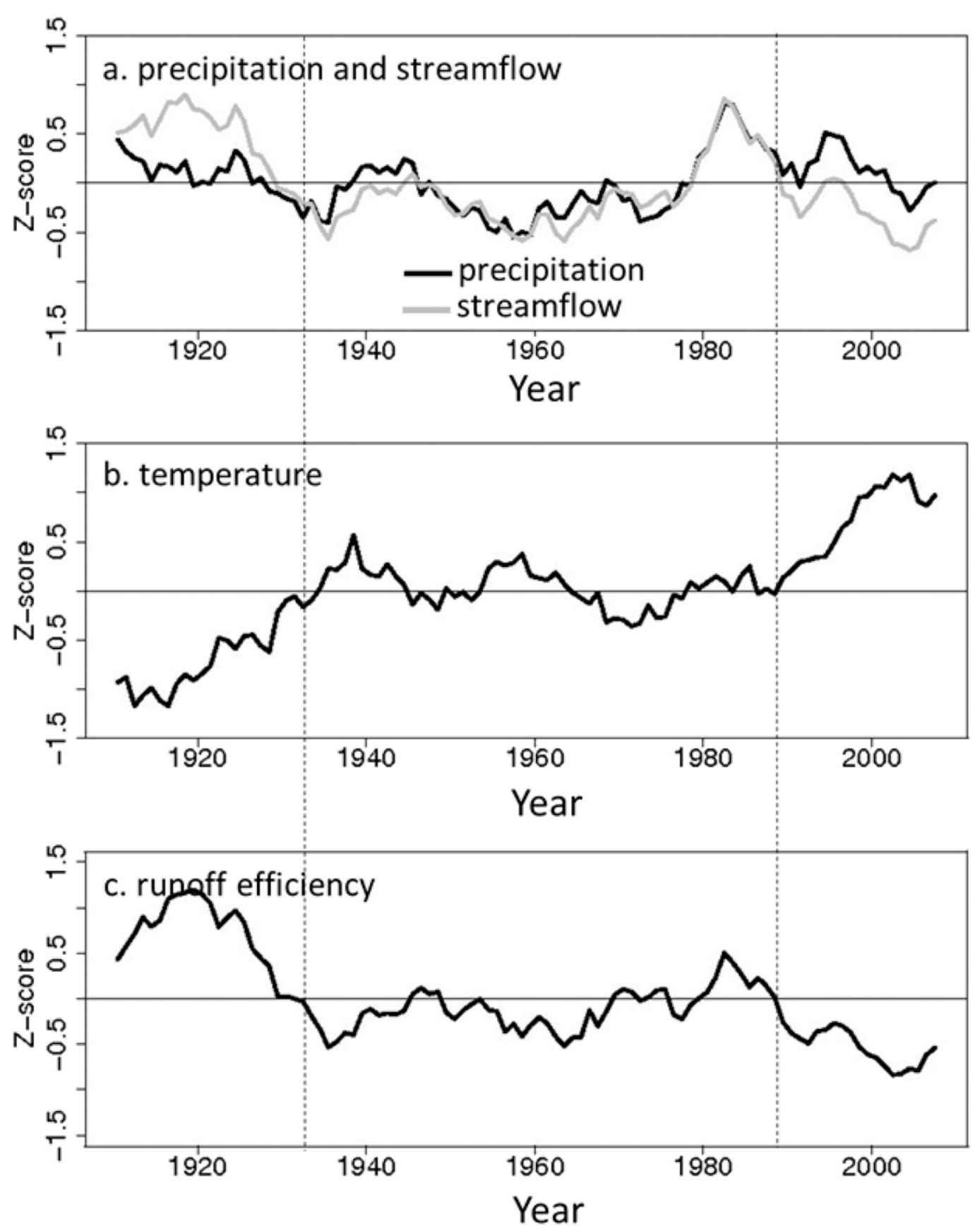

Figure 2. The 10-yr moving averages of $Z$ scores of upper Colorado River basin (a) water-year precipitation and streamflow, (b) water-year temperature, and (c) runoff efficiency. The dotted vertical lines demark an early twentiethcentury cool period (1906-33), a near-average temperature period (1934$87)$, and a late warm period (1988-2012). 
Earth Interactions - Volume 21 (2017) • Paper No. 10 • Page 8

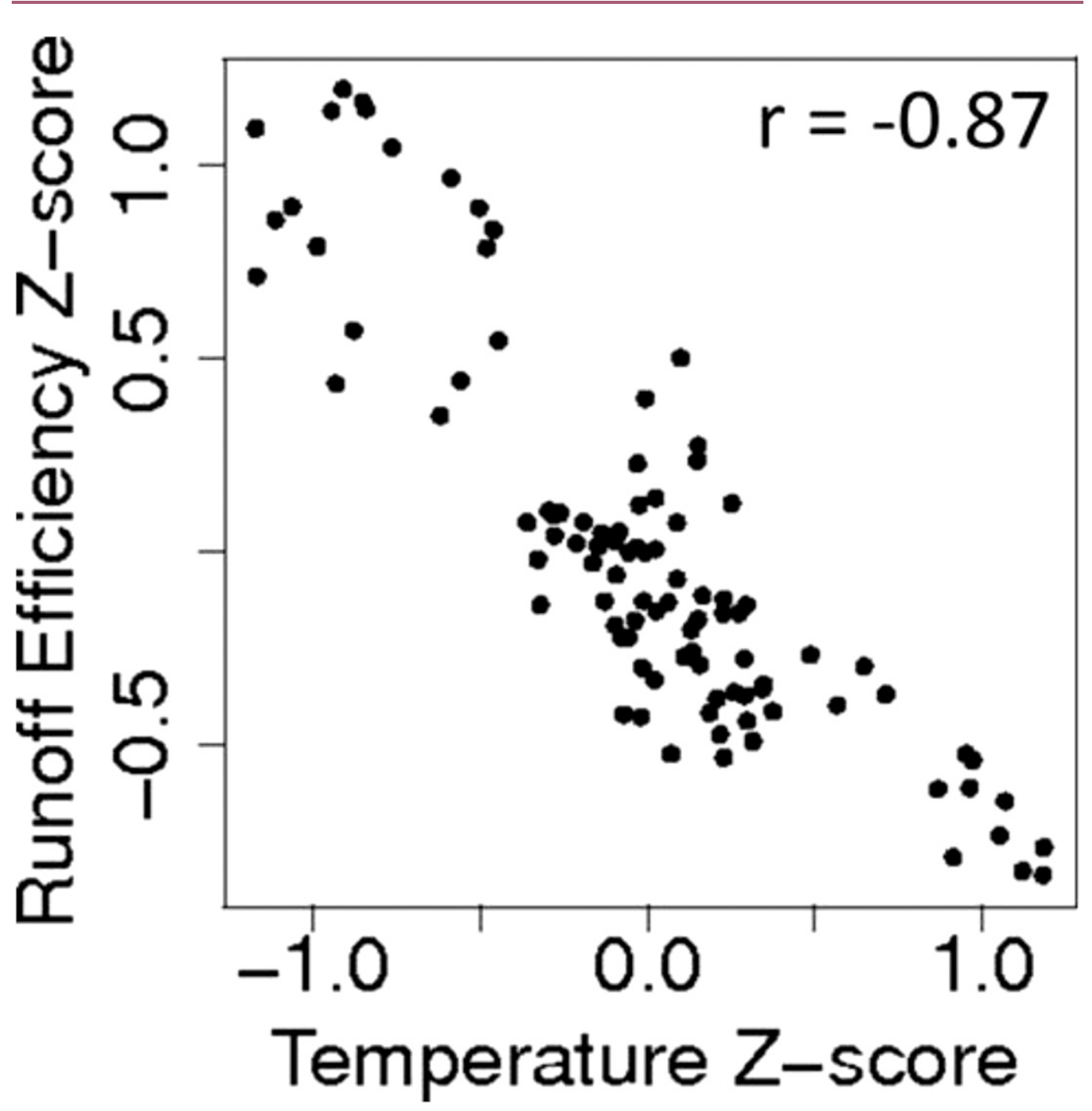

Figure 3. Comparison of 10-yr moving-average Z scores of water-year temperature with 10-yr moving-average $Z$ scores of runoff efficiency (water-year streamflow/water-year precipitation). The correlation coefficient $r$ for the comparison is indicated in the upper right-hand corner.

United States since about 1980 and related the decreases in SWE to increased temperature. McCabe and Wolock (2009) also reported that the post-1980, lowerthan-average SWE conditions in the western United States were unprecedented within the context of the twentieth century. Furthermore, Pederson et al. (2011) show, using the tree-ring-based reconstruction of 1 April SWE, that the magnitude of recent declines in SWE across the western United States is highly unusual in the context of the past 800 years. Recent tree-ring-based assessments of changes in runoff efficiency over the past 500 years for the UCRB and the upper Rio Grande River basin (Lehner et al. 2017) also show strong evidence for significant temperaturedriven flow declines since the mid-1980s. 
Earth Interactions - Volume 21 (2017) • Paper No. 10 • Page 9

Table 1. Regression of water-year upper Colorado River flow $(\mathrm{mcm})$ against wateryear UCRB temperature $\left(T ;{ }^{\circ} \mathrm{C}\right)$ and water-year UCRB precipitation $(P ; \mathrm{mcm})$. The coefficient of determination $r^{2}=0.70$ and adjusted $r^{2}=0.70\left(p<2.2 \times 10^{-16} 16\right)$.

\begin{tabular}{lclrc}
\hline & Intercept/coefficients & Standard error & $t$ value & $p$ value \\
\hline Intercept & $1.1414 \times 10^{4}$ & $3.817 \times 10^{3}$ & 3.704 & 0.0000341 \\
$T\left({ }^{\circ} \mathrm{C}\right)$ & $-2.489 \times 10^{3}$ & $4.130 \times 10^{2}$ & -6.027 & $2.56 \times 10^{-8}$ \\
$P(\mathrm{mcm})$ & $1.955 \times 10^{-1}$ & $1.708 \times 10^{-2}$ & 11.442 & $<2 \times 10^{-16}$ \\
\hline
\end{tabular}

To quantitatively assess the effects of water-year UCRB temperature and precipitation on water-year UCRB streamflow, a multiple linear regression analysis was performed with water-year UCRB streamflow as the dependent variable and water-year UCRB temperature and precipitation as the independent variables. The regression resulted in an adjusted coefficient of determination of $0.70(p<$ 0.0001 ), and the regression coefficients for both temperature and precipitation were statistically significant at $p<0.0001$ (Table 1). These regression results are nearly the same as those obtained by Nowak et al. (2012) who performed a regression of UCRB runoff against UCRB temperature and precipitation for the 1906-2006 period. The regression $t$ values for water-year UCRB temperature and precipitation were $-6.027(p<0.0001)$ and $11.442(p<0.0001)$, respectively. These $t$ values reflect a negative correlation between temperature and streamflow and a positive correlation between precipitation and streamflow. Additionally, the magnitude of the $t$ values indicates that the effects of interannual variability in precipitation on streamflow are almost twice as large as the effect of interannual variability in temperature on streamflow. The larger effect of precipitation on interannual streamflow variability is consistent with previous research that showed that precipitation is the primary source of interannual variability in UCRB streamflow (McCabe and Wolock 2011; Woodhouse et al. 2016).

To compute contributions of each of these variables to water-year UCRB streamflow for each year, the regression coefficient for temperature was multiplied by the time series of water-year UCRB temperature, and the regression coefficient for precipitation was multiplied by the time series of water-year UCRB precipitation. The resulting time series were smoothed with a 10 -yr moving average to remove highfrequency variability and to make the time series easier to interpret (Figure 4). The contributions of water-year UCRB temperature and precipitation to water-year UCRB streamflow are presented as contributions to UCRB flow departures 1) in million cubic meters and 2) as a percent of the long-term (1906-2012) mean streamflow.

This analysis allows a quantitative assessment of the contributions of water-year temperature and precipitation to streamflow departures over the period of record. The contributions of temperature are mostly positive during the early twentieth century because of cooler-than-average temperatures, with contributions that vary above and below zero from the early 1930s to the late 1980s (near-average temperature) and then mostly negative contributions from warm temperatures after the late 1980s (Figure 4). The most consistently negative temperature contributions to water-year UCRB streamflow departures over the entire 1906-2012 period have occurred since the late 1980s, coinciding with the warming trend in Figure 2b. The mean temperature contribution to water-year UCRB streamflow departures during the 1988-2012 period is $-1306 \mathrm{mcm}(-7 \%$ of mean water-year streamflow) or about 0.24 standard deviations of water-year UCRB streamflow. This temperature 
Earth Interactions - Volume 21 (2017) • Paper No. 10 • Page 10

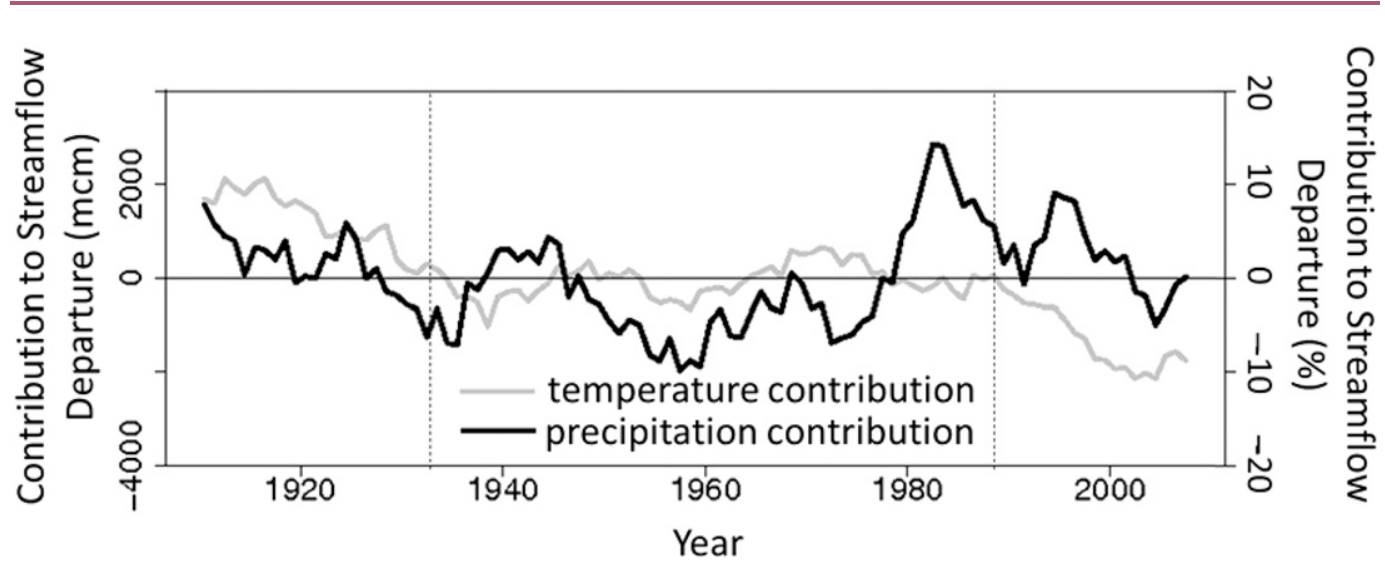

Figure 4. The 10-yr moving averages of the contributions of upper Colorado River basin water-year precipitation and temperature to water-year streamflow departures from the long-term (1906-2012) mean (mcm; left $y$ axis) and percent of the long-term mean of UCRB streamflow (right $y$ axis). The dotted vertical lines demark an early twentieth-century cool period (1906-33), a near-average temperature period (1934-87), and a late warm period (1988-2012).

effect on water-year UCRB streamflow departures is consistent with results in Udall and Overpeck (2017), who reported that from 2000 through 2014 UCRB streamflow was about $19 \%$ below the long-term average, with one-third or more of this decrease (at least $\sim 6 \%$ ) attributable to increased temperature.

The statistical significance of changes in temperature contributions to UCRB streamflow departures during the time period was computed using a Student's $t$ test. Comparing the temperature contribution to UCRB streamflow departures for 1906-33 with the temperature contribution from 1934 through 1987 resulted in a $t$ statistic value of -4.4887 ( $p<0.00004$; Table 2 ). This result suggests that there was a statistically significant decrease in contributions of temperature to UCRB streamflow departures from the positive temperature contributions during 1906-33 (a cool period) to the 1934-87 period (near-average temperature period; Figure 2b). Similarly, a Student's $t$ test comparing temperature contributions to UCRB streamflow departures for the 1934-87 period with temperature contributions for the 1988-2012 period resulted in a $t$ statistic value of $-3.0952(p<0.004$; Table 2). This indicates that the negative contributions of temperature to UCRB streamflow

Table 2. Results of Student's $t$ tests comparing the contributions of water-year UCRB temperature to water-year UCRB flow for different periods: 1906-33, 1934-87, and 1987-2012. The mean contributions of temperature to UCRB flow are in million cubic meters.

\begin{tabular}{llcccc}
\hline \multicolumn{7}{c}{ Mean } \\
\hline Period 1 & \multicolumn{1}{c}{ Period 2 } & Period 1 $(\mathrm{mcm})$ & Period 2 $(\mathrm{mcm})$ & $t$ statistic & \multicolumn{1}{c}{$p$ value } \\
\hline $1906-33$ & $1934-87$ & 1450.2620 & -146.5335 & -4.4887 & $3.268 \times 10^{-5}$ \\
$1934-87$ & $1988-2012$ & -146.5335 & -1307.7811 & -3.0952 & 0.003199 \\
\hline
\end{tabular}


Earth Interactions - Volume 21 (2017) • Paper No. 10 • Page 11

Table 3. Regression of water-year upper Colorado River flow $(\mathrm{mcm})$ against cool- $(\mathrm{Oc}-$ tober-March) and warm-season (April-September) UCRB temperature $T_{\text {cool }}$ and $T_{\text {warm }}\left({ }^{\circ} \mathrm{C}\right.$ ) and cool- and warm-season UCRB precipitation $P_{\text {cool }}$ and $P_{\text {warm }}(\mathrm{mcm})$. The coefficient of determination $r^{2}=0.76$ and adjusted $r^{2}=0.75\left(p<2.2 \times 10^{-16}\right)$.

\begin{tabular}{lccrc}
\hline & Intercept/coefficients & Standard error & $t$ value & $p$ value \\
\hline Intercept & 25192.098 & 6978.135 & 3.610 & 0.000476 \\
$T_{\text {cool }}\left({ }^{\circ} \mathrm{C}\right)$ & -627.963 & 270.702 & -2.320 & 0.022346 \\
$T_{\text {warm }}\left({ }^{\circ} \mathrm{C}\right)$ & -1960.112 & 418.885 & -4.679 & $8.87 \times 10^{-6}$ \\
$P_{\text {cool }}(\mathrm{mcm})$ & 75.013 & 7.095 & 10.573 & $<2 \times 10^{-16}$ \\
$P_{\text {warm }}(\mathrm{mcm})$ & 29.486 & 7.033 & 4.192 & $5.89 \times 10^{-5}$ \\
\hline
\end{tabular}

departures during 1988-2012 were statistically different from the more neutral temperature contributions to UCRB streamflow departures during 1934-87.

In addition to evaluating effects of changes in annual precipitation and temperature on streamflow, we also investigated the relative importance of cool(October-March) and warm-season (April-September) climate on UCRB streamflow. In this multiple regression analysis, the dependent variable was wateryear UCRB streamflow, and the independent variables were cool-season temperature, warm-season temperature, cool-season precipitation, and warm-season precipitation (Table 3). The resulting regression had an adjusted coefficient of determination of $0.75(p<0.00001)$, and the $t$ values were -2.320 for coolseason temperature $(p=0.022346),-4.679$ for warm-season temperature $(p<$ $0.00001), 10.573$ for cool-season precipitation $(p<0.00001)$, and 4.192 for warm-season precipitation $(p<0.00006$ ). These results indicate that cool-season precipitation has had the largest effect on variability in water-year UCRB streamflow, with warm-season precipitation and temperature having similar effects on water-year streamflow that are slightly less than half as large as the cool-season precipitation effects. Cool-season temperature had the smallest effect on the variability in water-year UCRB streamflow. These results are consistent with those of Woodhouse et al. (2016), who found that cool-season precipitation explains most of the variability in water-year UCRB streamflow and that spring/summer temperature can have substantial effects on UCRB streamflow under certain conditions. The greater contribution of warm-season temperature versus cool-season temperature to variability of UCRB flow suggests that evaporation or snowmelt, rather than changes from snow to rain during the cool season, have driven recent reductions in UCRB flow. These results are consistent with the findings of Foster et al. (2016), who examined the effects of warming on the hydrology of two mountain watersheds in the central Rocky Mountains and reported that warminginduced shifts in precipitation from snow to rain had a smaller effect on decreases in runoff than did warming-driven increases in summer evapotranspiration.

\section{Conclusions}

The results of this study provide evidence of a marked negative effect of temperature on UCRB flow over the past three decades. This study goes beyond prior work and quantifies the impact of warming temperatures, over both the full year and for the warm and cool seasons (e.g., Woodhouse et al. 2016; Udall and Overpeck 2017).

Examination of water-year UCRB temperature, precipitation, and streamflow time series indicate three periods of note: 1906-33 (cooler-than-average 
Earth Interactions - Volume 21 (2017) - Paper No. 10 • Page 12

temperature), 1934-87 (near-average temperature period), and 1988-2012 (warmer-than-average temperature). During the 1906-33 period, when temperature was cooler than average, streamflow $Z$ scores were generally higher than precipitation $Z$ scores, and runoff efficiency $Z$ scores were mostly higher than the long-term average value. In contrast, during the 1988-2012 period, when temperature was warmer than average, streamflow $Z$ scores were lower than precipitation $Z$ scores (indicating a lower runoff efficiency). These comparisons indicate that since about the late 1980s, temperature has had a notable negative effect driving reductions in UCRB runoff efficiency.

The degree to which changing temperatures are influencing UCRB streamflow, and the unusual strength of this influence in recent decades, is highlighted by regression analysis results. An important result from this analysis is that the contribution of water-year UCRB temperature to water-year UCRB streamflow departures has been consistently negative since the late 1980s, and the negative temperature contributions have been the largest of the 1906-2012 period. This negative impact translates to a mean departure in flow of $-1306 \mathrm{mcm}$ or $7 \%$ of water-year flow. More specifically, the negative impacts of temperature are most marked in the warm season. To put the mean $-1306 \mathrm{mcm}$ departure in water-year UCRB flow in context, this magnitude of decrease in UCRB flow is approximately $24 \%$ of the allotment of UCRB flow to California, or $38 \%$ of the allotment to Arizona, or $353 \%$ of the allotment of UCRB flow to Nevada (these percentages are based on the Boulder Canyon Project Act of 1928; see https://www.usbr.gov/ lc/region/g1000/lawofrvr.html and https://www.usbr.gov/lc/region/g1000/pdfiles/ bcpact.pdf).

These results suggest that if temperatures continue to increase, as projected by climate models (Udall and Overpeck 2017), there will be an increasing negative effect of temperature in driving larger-magnitude streamflow declines in the UCRB. This result has implications for water supply variability in general, but it is particularly important to note that the impacts of future drought will be exacerbated by this underlying warming. A twentieth-century-type drought, such as the 1950s, occurring in the future will have greater impacts on water supply because of the elevated temperatures. Recognizing the potential for more persistent and severe droughts than those that have occurred during the instrumental period, or documented in paleoclimatic records (e.g., Woodhouse et al. 2006; Meko et al. 2007), adds to the importance of these findings. A shift to dry conditions associated with precipitation reductions caused by natural climatic variability in combination with increased temperatures likely will result in droughts of unprecedented severity.

Acknowledgments. This work was supported in part by the DOI Southwest Climate Science Center Grant G14AP00152. We thank Julie Kiang (U.S. Geological Survey) and two anonymous reviewers for comments that helped improve the manuscript.

\section{References}

Christensen, N. S., and D. P. Lettenmaier, 2007: A multimodel ensemble approach to assessment of climate change impacts on the hydrology and water resources of the Colorado River basin. Hydrol. Earth Syst. Sci., 11, 1417-1430, https://doi.org/10.5194/hess-11-1417-2007. 
Earth Interactions - Volume 21 (2017) • Paper No. 10 • Page 13

— - W. Wood, N. Voisin, D. Lettenmaier, and R. N. Palmer, 2004: The effects of climate change on the hydrology and water resources of the Colorado River basin. Climatic Change, 62, 337 363, https://doi.org/10.1023/B:CLIM.0000013684.13621.1f.

Diaz, H. F., and C. A. Anderson, 1995: Precipitation trends and water consumption related to population in the southwestern United States: A reassessment. Water Resour. Res., 31, 713720, https://doi.org/10.1029/94WR02755.

Ficklin, D. L., I. T. Stewart, and E. P. Maurer, 2013: Climate change impacts on streamflow and subbasin-scale hydrology in the upper Colorado River basin. PLoS One, 8, e71297, https:// doi.org/10.1371/journal.pone.0071297.

Foster, L. M., L. A. Bearup, N. P. Molotch, P. D. Brooks, and R. M. Maxwell, 2016: Energy budget increases reduce mean streamflow more than snow-rain transitions: Using integrated modeling to isolate climate change impacts on Rocky Mountain hydrology. Environ. Res. Lett., 11, 044015, https://doi.org/10.1088/1748-9326/11/4/044015.

Hoerling, M., and J. Eischeid, 2007: Past peak water in the Southwest. Southwest Hydrology, Vol. 6, SAHRA, Southwest Hydrology, University of Arizona, Tucson, AZ, 18-19, 35, http:// www.swhydro.arizona.edu/archive/V6_N1/feature2.pdf.

Jacobs, J., 2011: The sustainability of water resources in the Colorado River basin. Bridge, 41, 612, https://www.nae.edu/19582/Bridge/55183/55194.aspx.

Kopytkovskiy, M., M. Geza, and J. E. McCray, 2015: Climate-change impacts on water resources and hydropower potential in the upper Colorado River basin. J. Hydrol. Reg. Stud., 3, 473493, https://doi.org/10.1016/j.ejrh.2015.02.014.

Lehner, F., E. R. Wahl, A. W. Wood, D. B. Blatchford, and D. Llewellyn, 2017: Assessing recent declines in upper Rio Grande River runoff efficiency from a paleoclimate perspective. Geophys. Res. Lett., 44, 4124-4133, https://doi.org/10.1002/2017GL073253.

McCabe, G. J., and M. P. Clark, 2005: Trends and variability in snowmelt runoff in the western United States. J. Hydrometeor., 6, 476-482, https://doi.org/10.1175/JHM428.1.

- and D. M. Wolock, 2007: Warming may create substantial water supply shortages in the Colorado River basin. Geophys. Res. Lett., 34, L22708, https://doi.org/10.1029/ 2007GL031764.

—, and — 2009: Recent declines in western U.S. snowpack in the context of twentiethcentury climate variability. Earth Interact., 13, https://doi.org/10.1175/2009EI283.1.

$\longrightarrow$, and - 2011: Independent effects of temperature and precipitation on modeled runoff in the conterminous United States. Water Resour. Res., 47, W11522, https://doi.org/10.1029/ 2011WR010630.

Meko, D. M., C. A. Woodhouse, C. A. Baisan, T. Knight, J. J. Lukas, M. K. Hughes, and M. W. Salzer, 2007: Medieval drought in the upper Colorado River basin. Geophys. Res. Lett., 34, L10705, https://doi.org/10.1029/2007GL029988.

Nowak, K., M. Hoerling, B. Rajagopalan, and E. Zagona, 2012: Colorado River Basin hydroclimatic variability. J. Climate, 25, 4389-4403, https://doi.org/10.1175/JCLI-D-11-00406.1.

Oyler, J. W., A. Ballantyne, K. Jencso, M. Sweet, and S. W. Running, 2015a: Creating a topoclimatic daily air temperature dataset for the conterminous United States using homogenized station data and remotely sensed land skin temperature. Int. J. Climatol., 35, 2258-2279, https://doi.org/ $10.1002 /$ joc. 4127.

— S. Z. Dobrowski, A. P. Ballantyne, A. E. Klene, and S. W. Running, 2015b: Artificial amplification of warming trends across the mountains of the western United States. Geophys. Res. Lett., 42, 153-161, https://doi.org/10.1002/2014GL062803.

Pederson, G. T., and Coauthors, 2011: The unusual nature of recent snowpack declines in the North American cordillera. Science, 333, 332-335, https://doi.org/10.1126/ science. 1201570.

Stewart, I. T., D. R. Cayan, and M. D. Dettinger, 2004: Changes in snowmelt runoff timing in western North America under a 'business as usual' climate scenario. Climatic Change, 62, 217-232, https://doi.org/10.1023/B:CLIM.0000013702.22656.e8. 
Earth Interactions - Volume 21 (2017) • Paper No. 10 • Page 14

Udall, B., and J. Overpeck, 2017: The twenty-first century Colorado River hot drought and implications for the future. Water Resour. Res., 53, 2404-2418, https://doi.org/10.1002/ 2016WR019638.

U.S. Bureau of Reclamation, 2012: Colorado River basin water supply and demand study: Executive summary. U.S. Department of the Interior, Bureau of Reclamation, 28 pp., https://www.usbr. gov/watersmart//bsp/docs/finalreport/ColoradoRiver/CRBS_Executive_Summary_FINAL.pdf.

Vano, J. A., and Coauthors, 2014: Understanding uncertainties in future Colorado River streamflow. Bull. Amer. Meteor. Soc., 95, 59-78, https://doi.org/10.1175/BAMS-D-12-00228.1.

Woodhouse, C. A., S. T. Gray, and D. M. Meko, 2006: Updated streamflow reconstructions for the upper Colorado River basin. Water Resour. Res., 42, W05415, https://doi.org/10.1029/ 2005WR004455.

— G. T. Pederson, K. Morino, S. A. McAfee, and G. J. McCabe, 2016: Increasing influence of air temperature on upper Colorado River streamflow. Geophys. Res. Lett., 43, 2174-2181, https://doi.org/10.1002/2015GL067613.

Earth Interactions is published jointly by the American Meteorological Society, the American Geophysical Union, and the Association of American Geographers. For information regarding reuse of this content and general copyright information, consult the AMS Copyright Policy (www.ametsoc.org/PUBSReuseLicenses). 